\title{
EVALUASI INSTALASI POMPA AIR TENAGA SURYA DI INDONESIA DENGAN MENGGUNAKAN STANDAR IEC 62253-2011
}

\author{
Evaluation of Solar Water Pumps Installation in Indonesia Using Standards IEC 62253- \\ 2011
}

\author{
Danar A. Susanto, Utari Ayuningtyas, Hermawan Febriansyah dan Meilinda Ayundyahrini \\ Pusat Penelitian dan Pengembangan Standardisasi, Badan Standardisasi Nasional \\ Gedung I BPPT Lantai 12, Jalan M.H. Thamrin No. 8, Jakarta, Indonesia \\ e-mail: danar@bsn.go.id
}

Diterima: 11 April 2018, Direvisi: 26 Juli 2018, Disetujui: 30 Juli 2018

\begin{abstract}
Abstrak
Pompa air dengan menggunakan tenaga surya sudah mulai banyak diaplikasikan di Indonesia, khususnya di daerah terpencil dengan keterbatasan jaringan listrik dan sulitnya bahan bakar minyak. Pemasangan Pompa Air Tenaga Surya (PATS) untuk daerah terpencil sangat menguntungkan, baik dari segi sosial, ekonomi maupun lingkungan. Namun, PATS yang terpasang tidak bisa maksimal efisiensinya bahkan dapat mengalami permasalahan dan kegagalan sistem apabila dipasang, digunakan dan pelihara tidak sesuai dengan prosedur. International Electrotechnical Commission (IEC) telah menetapkan standar IEC 62253-2011 tentang photovoltaic pumping systems - design qualification and performance measurements yang dapat digunakan sebagai panduan dan prosedur dalam instalasi sistem PATS. Tujuan dari penelitian ini adalah memetakan permasalahan pemasangan PATS dengan menggunakan parameter dalam standar IEC 62253-2011. Penelitian ini menggunakan metode analisis gap untuk mencari kesenjangan antara instalasi PATS di Indonesia dengan parameter standar IEC 62253-2011. Hasil penelitian melalui analisis gap menunjukkan bahwa 51\% aspek dalam IEC 62253-2011 tidak dipenuhi oleh pengguna yang memungkinkan menurunya efisiensi bahkan kegagalan sistem PATS, meskipun sebenarnya semua parameter dalam standar IEC 62253-2011 dapat dimungkinkan dipenuhi. Aspek paling besar yang tidak dipenuhi adalah terkait dengan ketersediaan buku pegangan operasi dan pemeliharaan untuk personil dan buku pegangan pemeliharaan yang mencakup operasi dan perbaikan. Hal ini sangat memungkinkan ketidaktahuan operator dalam memasang, mengoperasikan dan memelihara sistem, sehingga human error menjadi faktor yang paling dominan dalam aplikasi sistem PATS. Generator PV menjadi aspek produk yang paling banyak tidak sesuai dengan standar dengan presentase $71 \%$, meskipun sudah ada 22 SNI tentang PV yang meliputi modul, instalasi, pengujian dan konstruksi.
\end{abstract}

Kata kunci: pompa air tenaga surya, standar, daerah terpencil.

\begin{abstract}
Water pumps using solar power have been widely applied in Indonesia, especially in remote areas with limited power lines and the difficulty of fuel oil. Installation of Solar Water Pumps (PATS) for remote areas is very beneficial, both in terms of social, economic and environmental. However, the installed PATS can not maximize its efficiency even can experience problems and system failures when installed, used and maintained not in accordance with the procedure. The International Electrotechnical Commission (IEC) has established the IEC 62253-2011 standard on photovoltaic pumping systems - design qualification and performance measurements that can be used as guides and procedures for installing PATS systems. The purpose of this research is to map the problem of installation of PATS by using parameters in standard IEC 62253-2011. This research uses gap analysis method to find the gap between PATS installation in Indonesia with standard parameter of IEC 62253-2011. The results of the research through gap analysis indicate that 51\% aspect in IEC 62253-2011 is not fulfilled by users which enable decrease efficiency even PATS system failure, although in fact all parameters in IEC 62253-2011 standard can be possible fulfilled. The biggest aspect that is not met is related to the availability of operating and maintenance handbooks for personnel and maintenance handbooks that include operation and repair. This makes it possible for operator ignorance to install, operate and maintain the system, so that human error becomes the most dominant factor in PATS system application. The PV generator becomes the product aspect that most not complies with standard with percentage of $71 \%$, although there are 22 SNI about PV covering module, installation, testing and construction.
\end{abstract}

Keyword: photovoltaic pumping systems, standard, remote areas. 


\section{PENDAHULUAN}

Air merupakan salah satu produk alam yang paling banyak digunakan oleh manusia, seperti untuk minum, masak, sanitasi (MCK), industri, pertanian dan lain-lain. Meskipun air merupakan kebutuhan pokok manusia (Rahardjo, 2008), namun pada beberapa daerah dengan sumber mata air terbatas dan sulit dijangkau, ketersediaan air yang memenuhi syarat menjadi masalah. Meskipun peralatan pompanisasi tersedia, namun bahan bakar minyak atau listrik sebagai tenaga penggerak pompanisasi juga menjadi permasalahan sendiri.

Teknologi Pembangkit Listrik Tenaga Surya (PLTS) untuk menggerakkan pompa menjadi salah satu alternatif yang dapat mengatasi hambatan tersebut, hal ini karena Indonesia berada pada wilayah tropis, dimana cahaya matahari dapat diperoleh secara cuma-cuma sepanjang tahun. Kinerja PATS untuk memompa air menjadi sangat maksimal pada musim kemarau, dimana intensitas cahaya matahari dan kebutuhan air sangat tinggi. Sedangkan pada musim hujan, masyarakat bisa mendapatkan air dengan mudah, sehingga kinerja PATS yang kurang maksimal karena kurangnya intensitas cahaya matahari tidak menjadikan masalah.

Pompa air dengan menggunakan tenaga surya hanya memerlukan energi sinar matahari untuk operasionalnya. PATS akan tetap beroperasi meskipun cuaca mendung atau hujan sekalipun. Hal ini hanya berpengaruh terhadap debit energi yang dihasilkan. Keuntungan lain dari menggunakan sistem PATS yaitu tidak memerlukan operator khusus untuk mengoperasikan pompa ini, karena sistem ini beroperasi secara otomatis (Pranoto, 2011), mudah dipasang dan mudah dirawat (Bachtiar, 2006). Pompa tenaga surya tidak memerlukan pasokan solar dan juga tidak mengeluarkan gas emisi, sehingga jauh lebih bersih dan ramah lingkungan.

Pembangunan

PATS

juga

menguntungkan dari segi ekonomi. Pembangunan PATS menghasilkan nilai NPV (Net Present Value) positif, nilai IRR (Internal Rate of Return) sebesar $30 \%$ jika dibandingkan dengan harga pembelian dari truk tanki dan 34\% jika dibandingkan dengan harga pembelian dengan jerigen serta memiliki Net Benefit-Cost Ratio (Net B/C) lebih besar dari 1 yang menandakan bahwa sistem PATS menguntungkan dari sisi ekonomi (Arrohman, Sihana, \& Setiawan, 2012). Sedangkan dari aspek lingkungan, sistem PATS bisa mengurangi emisi $\mathrm{CO}_{2}$ selama rentang umur 25 tahun (Meah, Fletcher, \& Ula, 2008).

Meskipun memiliki banyak keuntungan, pemanfaatan PATS tidak bisa maksimal apabila pemasangan, pengoperasian dan pemeliharaan tidak dilakukan sesuai dengan prosedur. Menurut hasil penelitian Setiawan, Abdillah, \& Ismail (2014), pemasangan PATS mengalami penurunan kinerja dan efisiensi yang dikarenakan beberapa panel surya yang mengalami hot spot, pompa mengalami korosi dan scalling pada bagian mekanik dan controller mengalami kerusakan. Kinerja panel surya kurang maksimal dikarenakan pemasangan yang tidak sesuai antara beban dengan kapasitas yang dihasilkan oleh panel surya (Saputra, 2015). Faktor utama yang menyebabkan kerusakan sistem PATS adalah human error, hal ini dikarenakan masyarakat belum memiliki kemampuan teknis operasi dan pemeliharaan teknologi (Setiawan dkk, 2014).

Permasalahan-permasalahan yang ada ini perlu dimitigasi dengan suatu kebijakan atau regulasi (Setiawan dkk, 2014), sehingga PATS dapat difungsikan secara maksimal. Salah satu upaya dan bentuk kebijakan yang dapat diambil untuk meminimalkan permasalahan tersebut yaitu melalui penerapan standar.

Sampai dengan saat ini belum ada Standar Nasional Indonesia (SNI) mengenai sistem PATS, namun di International Electrotechnical Commission (IEC) telah ada standar IEC 62253-2011 tentang Photovoltaic pumping systems - Design qualification and performance measurements. Standar ini menetapakan kualifikasi desain dan pengukuran kinerja (performance) terkait produk sistem pompa air tenaga surya. Standar ini disusun untuk menetapkan prosedur verifikasi desain sistem pompa air tenaga surya yang sesuai dengan kondisi lingkungan tertentu (International Electrotechnical Commission, 2011).

Penelitian ini bertujuan untuk menganalisis dan mengevaluasi penerapan PATS di Indonesia dengan menggunakan parameter dalam standar IEC 62253-2011. Penelitian ini menggunakan analisis gap antara instalasi PATS di Indonesia dengan parameter dalam standar IEC 62253-2011, sehingga diperoleh data permasalahan, kesenjangan dan kemampuan pengguna PATS dalam menerapkan standar tersebut. Hasil dari analisis gap direkomendasikan untuk pengembangan Standar Nasional Indonesia (SNI) mengenai sistem pompa air tenaga surya yang sesuai dengan kondisi lingkungan di Indonesia.

\section{TINJAUAN PUSTAKA}

\subsection{Pompa Air Tenaga Surya}

Pompa air tenaga surya merupakan pompa air yang berfungsi menyedot air yang digerakkan dengan energi dari tenaga surya. Secara fisik, fungsi maupun instalasi pompa air ini mirip dengan pompa air konvensional, perbedaan mencolok ada pada panel surya yang menggenapi sistem pompa air sebagai sumber listrik yang menggerakkan 
pompa. Pompa air tenaga surya didasarkan pada teknologi photovoltaic (PV) yang mengubah sinar matahari menjadi listrik untuk memompa air. Panel PV dihubungkan kontroler untuk mengubah energi listrik yang dipasok oleh panel PV menjadi energi mekanik pada motor pompa. Putaran mekanis tersebut diubah menjadi energi hidrolik oleh pompa untuk menarik air.

Kapasitas suatu sistem pompa air tenaga surya untuk memompa air mempunyai 3 variabel fungsi utama yaitu tekanan, aliran, dan daya ke pompa (Chandel, Nagaraju Naik, \& Chandel, 2015). Tipe pompa air tenaga surya yang diterapkan di beberapa negara mempunyai konfigurasi yang berbeda-beda. Konfigurasi tipe pompa air tenaga surya disajikan pada Gambar 1 sampai dengan Gambar 3, sebagai berikut:

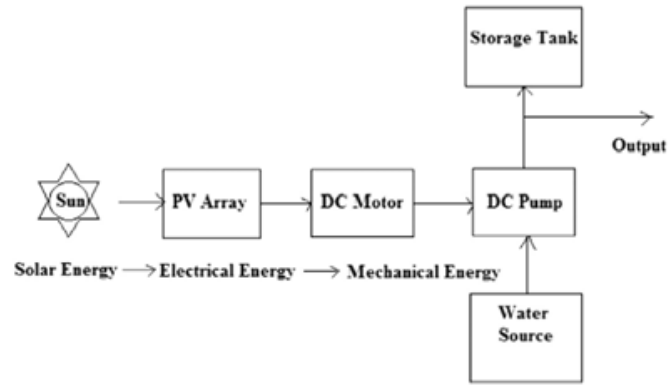

Gambar 1 Konfigurasi sistem pompa air tenaga surya (DC).

Sumber: (Chandel dkk, 2015).

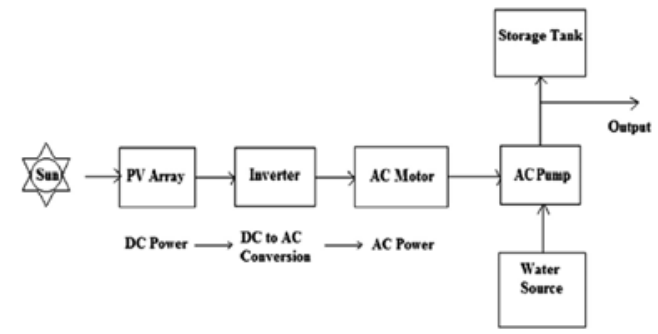

Gambar 2 Konfigurasi sistem pompa air tenaga surya (AC).

Sumber: (Chandel dkk, 2015).

Sistem pompa air tenaga surya banyak diaplikasikan untuk berbagai keperluan, antara lain untuk keperluan rumah tangga, irigasi, tambak, kolam renang dan lain-lain. Daya photovoltaic (PV) untuk irigasi mempunyai harga yang kompetitif dibandingkan dengan sumber energi tradisional untuk kebutuhan pemompaan air skala kecil. Dengan terus meningkatnya biaya bahan bakar fosil dan pengurangan biaya PV karena produksi massal, daya fotovoltaik akan menjadi lebih ekonomis di masa depan (Eker, 2005). Sistem pemompaan air bertenaga PV telah menjadi menarik bagi aplikasi peternakan dan pertanian di lokasi terpencil yang memiliki akses terbatas pada listrik konvensional.

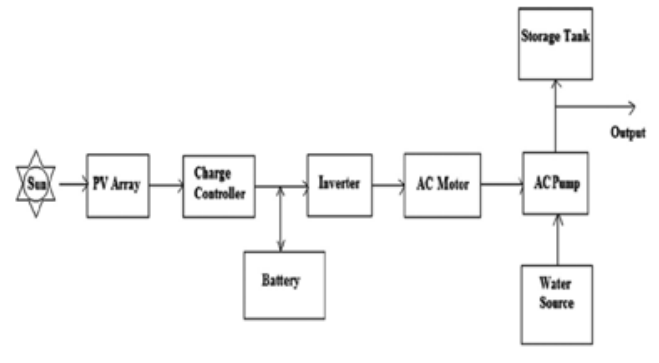

Gambar 3 Konfigurasi sistem pompa air tenaga surya dengan penyimpanan baterai.

Sumber: (Chandel dkk, 2015).

\subsection{Standar IEC 62253-2011}

International Electrotechnical Commission (IEC) telah menetapkan standar IEC 62253-2011 tentang photovoltaic pumping systems - Design qualification and performance measurements sebagai standar yang mengatur sistem pompa air tenaga surya. Standar ini mendefinisikan persyaratan untuk desain, kualifikasi dan pengukuran kinerja sistem pemompaan dengan tenaga surya (photovoltaic) dalam operasi yang berdiri sendiri (stand-alone operation).

Pengukuran berlaku untuk pengujian di dalam ruangan dengan simulator PV pembangkit atau pengujian di luar ruangan dengan menggunakan generator PV. Standar ini berlaku untuk sistem PATS dengan motor pompa set yang terhubung ke generator PV langsung atau melalui converter (DC ke DC atau DC ke AC). Standar ini tidak berlaku untuk sistem dengan penyimpanan listrik (baterai) kecuali hanya digunakan untuk pompa start up (<100 Wh). Tujuan pemberlakuan standar ini adalah untuk menetapkan prosedur verifikasi desain sistem pompa air tenaga surya yang sesuai dengan kondisi lingkungan tertentu. Standar ini membahas sistem pompa dengan desain sebagai berikut:

a) Karakteristik daya (power) dibandingkan dengan kecepatan aliran (flow rate) pada tinggi pemompaan yang tetap.

b) Karakteristik tinggi pemompaan dibandingkan dengan kecepatan aliran (flow rate) pada kecepatan tetap.

c) Parameter dan persyaratan sistem desain

d) Spesifikasi sistem

e) Persyaratan dokumentasi

f) Prosedur verifikasi sistem desain

Tujuan dari standar ini adalah untuk menetapkan persyaratan agar dapat memverifikasi karakteristik kinerja sistem pompa air tenaga surya (International Electrotechnical Commission, 2011).

\subsection{Analisis Gap}

Secara harfiah kata "gap" berarti mengindikasikan adanya suatu perbedaan (jenjang) antara satu hal dengan hal lainnya (Rachmi, Susanto, \& 
Herdiyanti, 2014). Gap analisis atau analis kesenjangan merupakan suatu metode yang digunakan untuk mengetahui kinerja dari sistem yang sedang berjalan dengan sistem standar (Muchsam, Falahah, \& Saputro, 2011). Sistem operasional dan strategi perusahaan dalam mencapai suatu tujuan, merupakan kinerja dari perusahaan. Gap analisis bermanfaat untuk:

a) Mengetahui nilai kesenjangan antara kinerja yang sebenarnya dengan standar yang direncanakan.

b) Mengetahui bagian dari kinerja yang perlu ditingkatkan untuk menutup kesenjangan.

c) Sebagai alat pengambilan keputusan untuk menentukan skala prioritas dan biayanya untuk standar kerja yang diharapkan (Muchsam dkk, 2011).

\section{METODE PENELITIAN}

Teknik pengumpulan data yang digunakan dalam penelitian ini mengunakan kuesioner dan dokumentasi. Kuesioner peneltiian terdiri dari 3 hal yaitu mengenai deskripsi umum responden, pertanyaan umum mengenai instalasi PATS dan pertanyaan khusus mengenai penerapan parameter standar IEC 62253-2011 dalam instalasi PATS. Pengumpulan data primer dari kuesioner dan dokumentasi diambil langsung melalui survei ke instalasi PATS. Populasi dalam penelitian ini adalah populasi yang tidak diketahui jumlahnya, karena tidak ada data pasti jumlah instalasi PATS di Indonesia. Metode pengambilan sampel yang digunakan adalah dengan metode non probability sampling karena populasi yang diteliti bersifat infinite (populasi dengan jumlah yang tidak diketahui). Dengan mempertimbangkan dana, waktu dan tenaga, penelitian ini menggunakan purposive sampling untuk menentukan jumlah sampel. Selain itu, pengambilan sampel dilakukan secara accidental sampling/convenience sampling. Menurut Santoso \& Tjiptono (2001), accidental sampling merupakan prosedur sampling yang memilih sampel dari satu orang atau unit yang paling mudah dijumpai atau diakses.

Jumlah sampel yang diperoleh dari penelitian ini adalah 25 responden instalasi PATS di Indonesia yang diperoleh di wilayah Daerah Istimewa Yogyakarta (Gunung Kidul), Jawa Tengah (Cilacap), Jawa Timur (Surabaya), Sumatera Barat (Padang, Payakumbuh, Agam dan Bukittinggi), Kalimantan Timur (Berau dan Taliyasan), Maluku Utara (Ternate, Sofifi dan Foramaidi) dan Nusa Tenggara Timur (Waikabubak dan Waingapu). Keragaman dan keterwakilan lokasi pengambilan sampel yang terdistribusi secara heterogen di beberapa pulau besar Indonesia, dapat mewakili sebagai sampel yang cukup dalam penelitian. Metode analisis penelitian menggunakan analisis gap untuk mencari kesenjangan antara parameter standar IEC 62253-2011 dengan instalasi PATS di Indonesia.

\section{HASIL DAN PEMBAHASAN}

Indonesia merupakan negara kepulauan terbesar di dunia dengan potensi sumber daya alam dan pariwisata yang tidak terbatas. Segala potensi ini perlu didukung dengan sarana dan prasarana yang baik, khususnya pada daerah-daerah terpencil dan terpelosok. Pasokan kebutuhan dasar di daerah terpencil tersebut, seperti air dan listrik masih menjadi kendala utama yang belum terpenuhi secara maksimal. Khusus untuk kebutuhan air, manusia akan kesulitan bertahan hidup tanpa adanya air, karena air merupakan kebutuhan pokok yang digunakan untuk keperluan hidup setiap hari. Krisis air dan keterbatasan pasokan listrik PLN di daerah terpencil dapat diatasi dengan memanfaatkan tenaga surya untuk memompa air. Pompa air tenaga surya adalah pompa air yang tenaga penggerak pompanya berasal dari tenaga surya. Pompa air tenaga surya tepat digunakan untuk daerah terpencil karena bekerja secara mandiri tanpa bergantung pada listrik dari PLN. Pompa air tenaga surya umumnya bekerja tanpa baterai dan bekerja menggunakan sinar matahari, sangat sesuai untuk daerah yang tidak terjangkau listrik.

\section{a. Instalasi PATS di Indonesia}

Hasil penelitian dengan melakukan survei ke-25 responden (installer, distributor, dan pengguna langsung) menunjukkan alasan bahwa pemasangan PATS merupakan hal yang penting yang dikarenakan belum adanya aliran listrik PLN dan ketersediaan sumber mata air jauh atau susah dijangkau. Sedangkan alasan yang lain adalah terkait dengan biaya listrik, bahan bakar dan biaya maintenance PATS lebih murah dibandingkan dengan mesin diesel. 


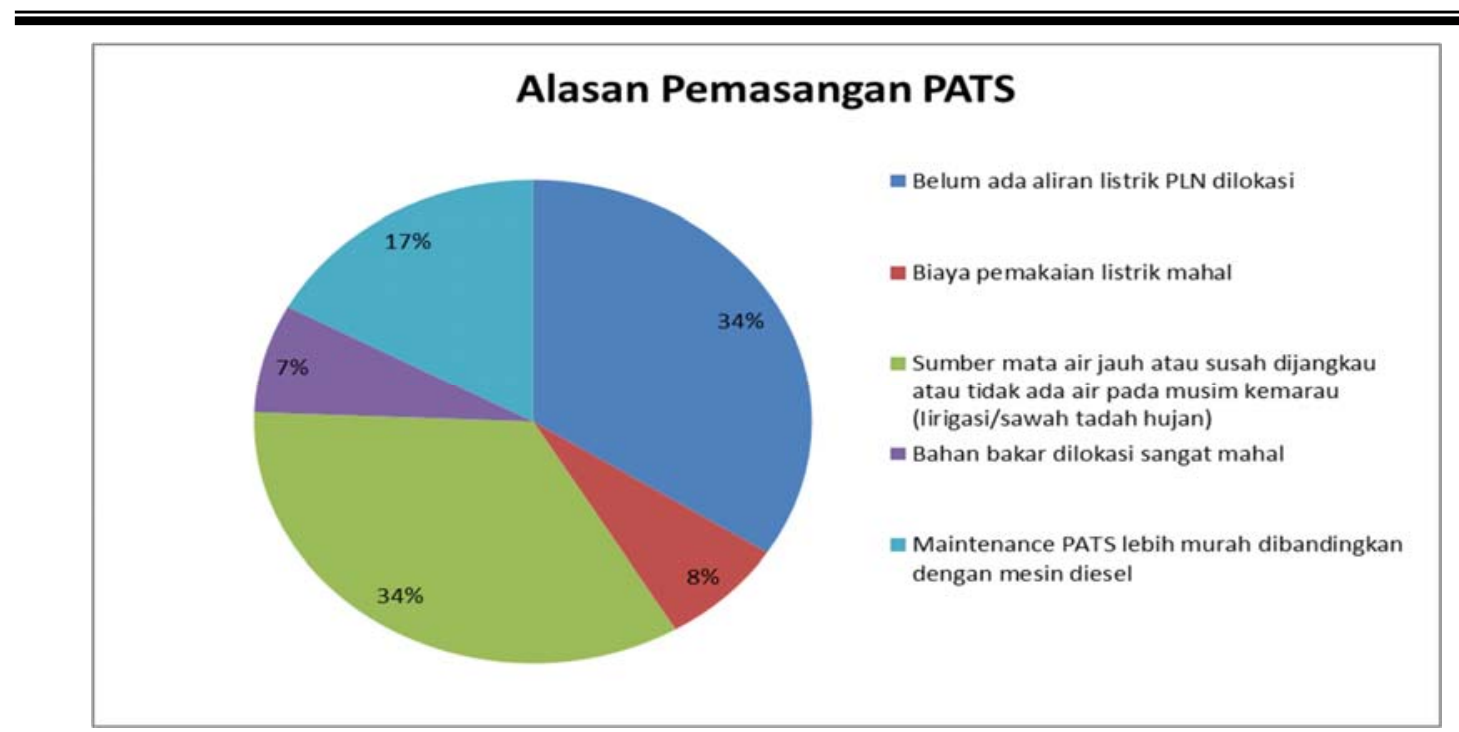

Gambar 4 Alasan pemasangan PATS.

Meskipun biaya investasi untuk instalasi PATS tidak murah, namun pengguna PATS merasakan manfaat yang lebih besar daripada harus membeli air atau menggunakan mesin diesel. Sistem PATS adalah pilihan ekonomis yang layak untuk kebutuhan konsumsi air masyarakat terpencil (Kaldellis, Meidanis, \& Zafirakis, 2011). Penghematan PATS cukup banyak dibandingkan dengan sistem konvensional (Rezae \& Gholamian, 2013).

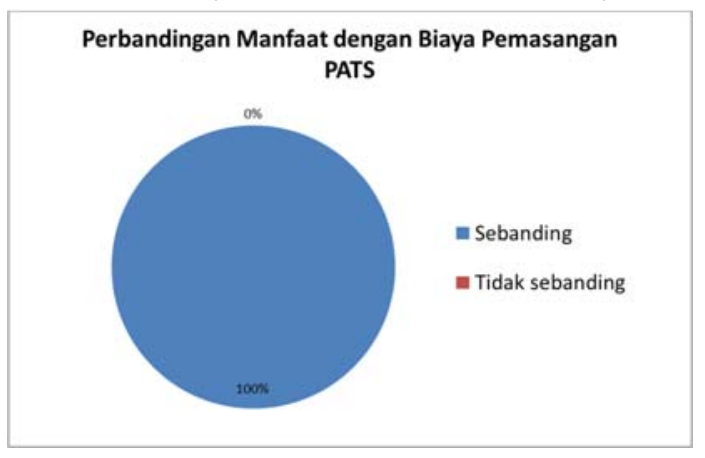

Gambar 5 Perbandingan manfaat dan biaya pemasangan PATS.

Secara keseluruhan, manfaat penerapan PATS banyak dirasakan oleh responden, sebagai berikut:

a. Kemudahan dalam mendapatkan air untuk kebuuhan sehari-hari

b. Terpenuhinya kebutuhan air untuk ternak dan tambak. c. Terpenuhinya kebutuhan air untuk pertanian, khususnya irigasi pada saat kemarau.

d. Tidak lagi membeli air, bayar listrik dan membeli bahan bakar untuk menghidupkan pompa.

Manfaat dan kelebihan PATS yang lain adalah pompa air tenaga surya sangat efektif, efisien dan tahan lama sampai dengan 25 tahun (Meah dkk, 2008). Dengan melihat kemudahan, manfaat, kelebihan dan umur pakai yang panjang, penggunaan pompa air tenaga surya menjadi alternatif yang banyak diminati untuk memenuhi kebutuhan pasokan air bersih pada daerah yang jauh dari jangkauan listrik. Meskipun biaya dan sumber daya yang dikeluarkan untuk instalasi PATS cukup besar, namun $100 \%$ responden menyatakan bahwa manfaat yang diperoleh sebanding dengan biaya yang dikeluarkan.

Pemasangan PATS bisa kembali modal termasuk subsidi pada modul PV dalam periode 6 tahun (Pande, dkk, 2003). Sedangkan pemasangan PATS di India bisa balik modal dalam periode kurang dari 4 tahun dengan penghematan besar selama 16 tahun (Jamil, Anees, \& Rizwan, 2012). Pemasangan SMART PATAS (Pompa Air Tenaga Surya) oleh LEN (PT Len Industri - Persero) di Gorontalo mampu menjaga stabilitas pasokan air ke lahan pertanian di musim kering sehingga terhindar dari puso atau kekeringan, lebih ekonomis jika dibanding dengan pompa air tenaga genset (Len Industri, 2016). 


\section{Kendala Pemasangan PATS}

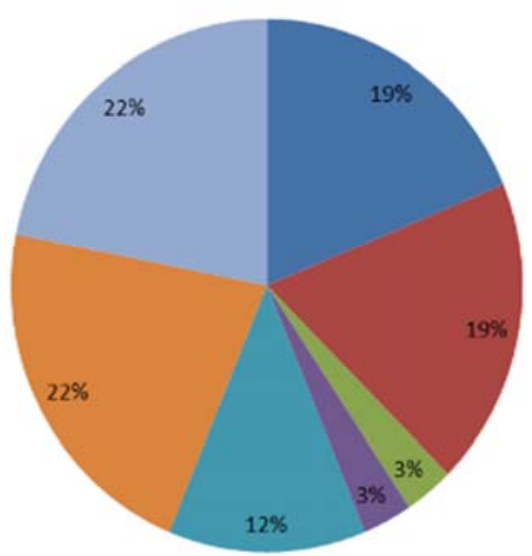

n Cuaca saat musim hujan

- Pipa sering pecah kena cangkul

= Galian sumber air (dari sungai) sering longsor

= Jalanan yang rusak akibatnya banyak PV yang pecah

= Lahan yang kurang sesuai atau susah terjangkau

nembebasan lahan

= Tidak ada

Dalam pemasangan PATS, ada beberapa kendala yang ditemui oleh responden. Kendala terbesar adalah terkait dengan aspek sosial, pembebasan lahan dan kurang sesuainya lahan tersebut (35\%). Kondisi Lahan ini merupakan lahan untuk pemasangan sel surya dan lokasi sumur (jika sumber air adalah sumur). Kendala lain adalah terkait dengan cuaca pada saat musim hujan dan pipa yang sering kena cangkul. Namun demikian, 22\% responden menyatakan tidak mengalami kendala dalam pemasangan dan pengoperasian PATS. b. Analisis Gap Antara Parameter IEC 62253-2011 Dengan instalasi PATS

Standar IEC 62253-2011 mendefinisikan persyaratan untuk desain, kualifikasi dan pengukuran kinerja sistem pemompaan dengan tenaga surya (fotovoltaic) dalam operasi yang berdiri sendiri (stand-alone operation). Parameter dalam untuk kinerja dan kualifikasi disajikan pada Tabel 1 , sebagai berikut:

Tabel 1 Parameter IEC 622532011.

\begin{tabular}{|c|c|c|c|c|}
\hline \multirow{2}{*}{ No } & \multirow{2}{*}{ Kriteria } & \multirow{2}{*}{ Uraian } & \multicolumn{2}{|c|}{$\begin{array}{l}\text { Pemenuhan Terhadap } \\
\text { Standar IEC 62253-2011 }\end{array}$} \\
\hline & & & Memenuhi & $\begin{array}{c}\text { Tidak } \\
\text { Memenuhi }\end{array}$ \\
\hline \multirow{2}{*}{1.} & \multirow{2}{*}{ Data Geografis } & Garis Bujur dan lintang & $67 \%$ & $33 \%$ \\
\hline & & Topografi & $67 \%$ & $33 \%$ \\
\hline \multirow{4}{*}{2.} & \multirow{4}{*}{ Data Iklim } & Iradiasi & $58 \%$ & $42 \%$ \\
\hline & & Data suhu & $67 \%$ & $33 \%$ \\
\hline & & Presipitasi & $42 \%$ & $58 \%$ \\
\hline & & $\begin{array}{l}\text { Kecepatan angin maksimal dan kecepatan angin } \\
\text { rata-rata }\end{array}$ & $46 \%$ & $54 \%$ \\
\hline \multirow{4}{*}{3.} & \multirow{4}{*}{$\begin{array}{l}\text { Kondisi lokal } \\
\text { spesifik }\end{array}$} & $\begin{array}{l}\text { Kedalaman sumber air (beda tinggi statik), } \\
\text { diameter sumber air }\end{array}$ & $67 \%$ & $33 \%$ \\
\hline & & $\begin{array}{l}\text { Produktivitas sumber air (Qmaks dalam } \mathrm{m}^{3} / \mathrm{jam} \text { dan } \\
\text { kemampuan maksimum pompa pada ketinggian } \\
\text { ini) dan kemampuan debit maksimum dari } \\
\text { sumber air }\end{array}$ & $67 \%$ & $33 \%$ \\
\hline & & $\begin{array}{l}\text { Ketinggian air dinamis (ditentukan berdasarkan } \\
\text { peraturan internasional/peraturan } \\
\text { nasional/peraturan daerah/perusahaan) }\end{array}$ & $29 \%$ & $71 \%$ \\
\hline & & $\begin{array}{l}\text { TDH (tinggi dinamik total, termasuk kehilangan } \\
\text { gesekan dari sistem pemipaan) }\end{array}$ & $67 \%$ & $33 \%$ \\
\hline
\end{tabular}




\begin{tabular}{|c|c|c|c|c|}
\hline \multirow{4}{*}{ No } & \multirow{4}{*}{ Kriteria } & \multirow{2}{*}{ Uraian } & \multicolumn{2}{|c|}{$\begin{array}{l}\text { Pemenuhan Terhadap } \\
\text { Standar IEC 62253-2011 }\end{array}$} \\
\hline & & & Memenuhi & $\begin{array}{c}\text { Tidak } \\
\text { Memenuhi }\end{array}$ \\
\hline & & $\begin{array}{l}\text { Pemenuhan pasokan air setiap hari pada kondisi } \\
\text { terburuk (radiasi, tanggal, tinggi air) }\end{array}$ & $8 \%$ & $92 \%$ \\
\hline & & $\begin{array}{l}\text { Kualitas air harus sesuai dengan peraturan } \\
\text { internasional atau nasional atau perusahaan, } \\
\text { indikasi kotor, atau partikel-partikel pasir. }\end{array}$ & $33 \%$ & $67 \%$ \\
\hline 4. & Permintaan air & $\begin{array}{l}\text { Profil konsumsi } \\
\text { (Total kepala keluarga dan jumlah orang) }\end{array}$ & $67 \%$ & $33 \%$ \\
\hline \multirow{8}{*}{5.} & \multirow{8}{*}{ Deskripsi proyek } & Deskripsi lokasi (termasuk foto, apabila tersedia) & $67 \%$ & $33 \%$ \\
\hline & & $\begin{array}{l}\text { Kondisi lokasi dengan data ketinggian untuk } \\
\text { menentukan Ketinggian air dinamis, TDH, sistem } \\
\text { pemipaan (panjang, diameter) }\end{array}$ & $67 \%$ & $33 \%$ \\
\hline & & Bangunan yang ada atau yang direncanakan & $29 \%$ & $71 \%$ \\
\hline & & Tanaman yang terkait dengan peneduh & $38 \%$ & $63 \%$ \\
\hline & & Fasilitas penyimpanan utama dan distribusi air & $42 \%$ & $58 \%$ \\
\hline & & $\begin{array}{l}\text { Tangki air, fasilitas distribusi atau penyimpanan } \\
\text { lain termasuk spesifikasi teknis*. }\end{array}$ & $17 \%$ & $83 \%$ \\
\hline & & $\begin{array}{l}\text { Spesifikasi lifetime konstruksi instalasi PVIPV } \\
\text { racking }\end{array}$ & $42 \%$ & $58 \%$ \\
\hline & & $\begin{array}{l}\text { Proteksi terhadap petir/sistem grounding } \\
\text { (pembumian) }\end{array}$ & $42 \%$ & $58 \%$ \\
\hline \multirow{2}{*}{6.} & \multirow{2}{*}{ Lain-lain } & Perkiraan jam produksi & $46 \%$ & $54 \%$ \\
\hline & & Box controller (pelindung) & $67 \%$ & $33 \%$ \\
\hline \multirow{6}{*}{7.} & \multirow{6}{*}{$\begin{array}{l}\text { Buku Pegangan } \\
\text { operasi dan } \\
\text { pemeliharaan } \\
\text { untuk personel }\end{array}$} & $\begin{array}{l}\text { Standar operasional Prosedur seperti } \\
\text { menyalakan (start-up) dan mematikan (shut- } \\
\text { down) }\end{array}$ & $4 \%$ & $96 \%$ \\
\hline & & $\begin{array}{l}\text { Deskripsi fungsi personil, deskripsi fungsi } \\
\text { pengawasan dan interpretasi indikator status dan } \\
\text { error. }\end{array}$ & $4 \%$ & $96 \%$ \\
\hline & & Aturan untuk tindakan kesalahan operasi & $4 \%$ & $96 \%$ \\
\hline & & Petunjuk tentang teknik keselamatan & $4 \%$ & $96 \%$ \\
\hline & & Tindakan perlindungan terhadap sengatan listrik & $4 \%$ & $96 \%$ \\
\hline & & Pekerjaan pemeliharaan (seperti pembersihan) & $25 \%$ & $75 \%$ \\
\hline \multirow{6}{*}{8.} & \multirow{6}{*}{$\begin{array}{l}\text { Buku pegangan } \\
\text { pemeliharaan } \\
\text { yang mencakup } \\
\text { operasi dan } \\
\text { perbaikan/ servis }\end{array}$} & Instruksi instalasi & $4 \%$ & $96 \%$ \\
\hline & & Deskripsi fungsi sistem instalasi & $4 \%$ & $96 \%$ \\
\hline & & $\begin{array}{l}\text { Instruksi pemeliharaan dan pengoperasian } \\
\text { dengan membuat jadwal pemeliharaan, dimulai } \\
\text { dari operasi awal sampai dengan penanganan } \\
\text { kesalahan. }\end{array}$ & $4 \%$ & $96 \%$ \\
\hline & & $\begin{array}{l}\text { Kesesuaian gambar skematik dalam bentuk } \\
\text { rencana dan aktual di lapangan (flow chart } \\
\text { system). }\end{array}$ & $4 \%$ & $96 \%$ \\
\hline & & $\begin{array}{l}\text { Diagram rangkaian listrik yang sesuai dengan } \\
\text { ketentuan dan rencana implementasi serta } \\
\text { aktualnya di lapangan (wiring and terminal } \\
\text { diagrams) }\end{array}$ & $4 \%$ & $96 \%$ \\
\hline & & $\begin{array}{l}\text { Daftar perangkat sistem yang sesuai dengan } \\
\text { gambar tekniknya }\end{array}$ & $4 \%$ & $96 \%$ \\
\hline
\end{tabular}




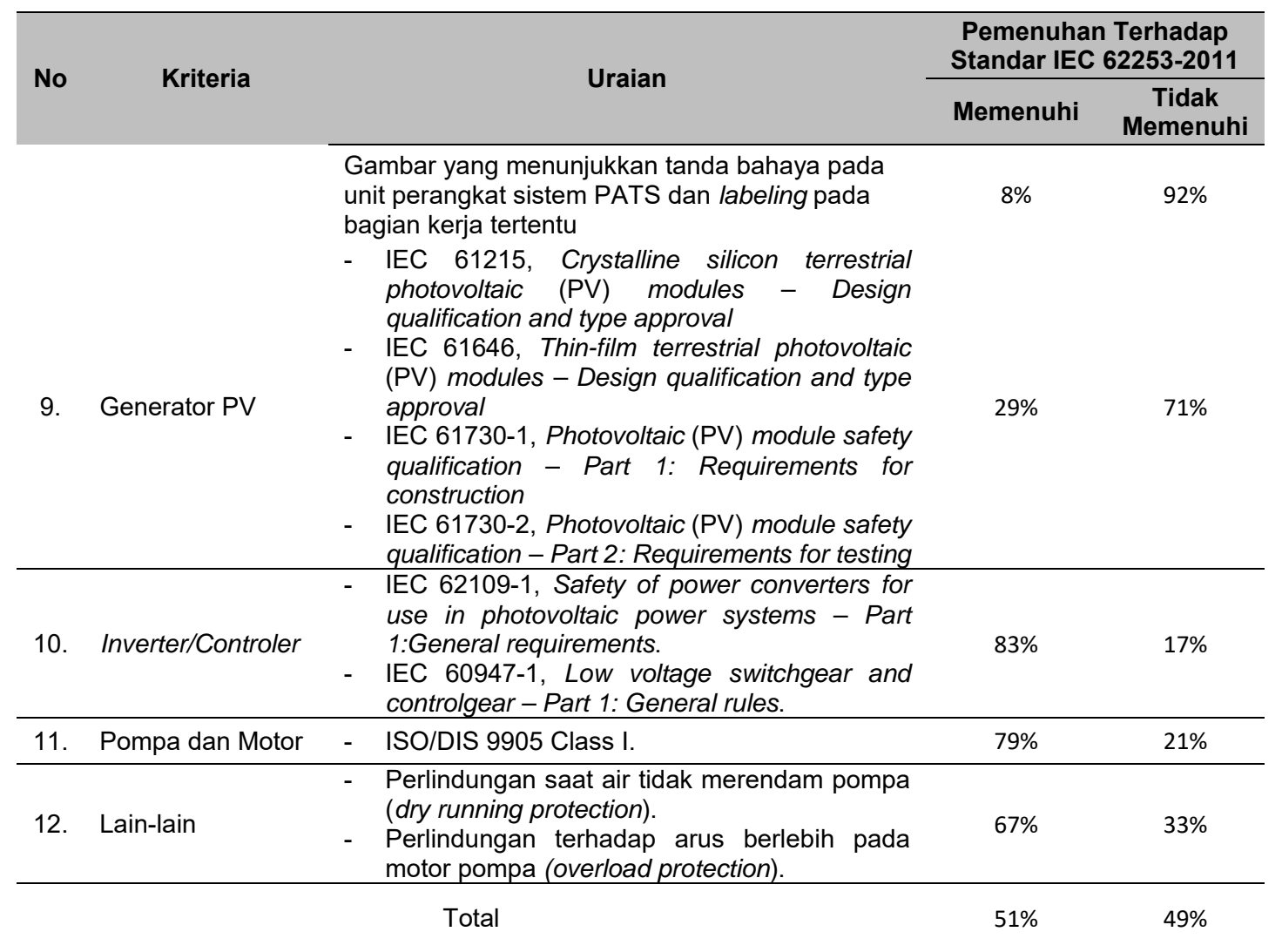

Sumber: (International Electrotechnical Commission, 2011).

Terdapat 12 aspek dalam standar IEC 622532011 yang disandingkan dengan instalalsi PATS di Indonesia. Aspek ini meliputi data geografis, data iklim, kondisi lokal spesifik, permintaan air, deskripsi proyek, lain-lain, buku pegangan operasai dan pemeliharaan untuk personel, buku pegangan pemeliharaan mencakup operasi dan perbaikan, generator photovoltaic, inverter/controller, pompa/motor dan lain-lain. Parameter 1 sampai dengan 6 merupakan parameter terhadap kebutuhan data sebelum memasang PATS. Data dari parameter ini digunakan untuk menentukan jumlah, ukuran dan lokasi pemasangan panel PV serta pompa yang akan digunakan untuk mengangkat air dari sumber air. Dari parameter ini juga dapat ditentukan peralatan pendukung seperti kabel, pipa, ukuran bak penampungan dan lain-lain. Buku manual yang terdiri dari buku pegangan operasi dan pemeliharaan untuk personel dan buku pegangan pemeliharaan yang mencakup operasi dan perbaikan atau servis merupakan parameter pendukung untuk personil yang melakukan operasi dan pemeliharaan serta installer PATS.

Hasil penelitian seperti pada Tabel 1 menunjukkan bahwa $51 \%$ parameter dalam IEC 62253 tidak dipenuhi oleh installer atau pengguna yang memungkinkan menurunnya efisiensi bahkan kegagalan sistem PATS. Aspek paling besar yang tidak dipenuhi adalah terkait dengan ketersediaan buku pegangan operasi dan pemeliharaan untuk personel dan buku pegangan pemeliharaan yang mencakup operasi dan perbaikan dengan persentase sebesar $95 \%$. Parameter ketersediaan buku manual bisa dikaitkan langsung dengan personil yang memasang, menggunakan serta memelihara PATS. Hal ini sesuai dengan dengan penelitian Setiawan dkk (2014) yang menyampaikan bahwa faktor utama yang menyebabkan kerusakan sistem PATS adalah human error, hal ini dikarenakan masyarakat belum memiliki kemampuan teknis operasi dan pemeliharaan teknologi. Apabila installer dan pengguna PATS memahami dan menerapkan standar ini, maka masalah pemasangan dan aplikasi PATS data diminimalisir.

Pada parameter 1 sampai dengan 6 yang merupakan parameter terhadap kebutuhan data sebelum memasang PATS diperoleh data bahwa $52 \%$ responden tidak memenuhi parameter standar IEC 62253. Berdasarkan data ini, cukup banyak responden yang memasang PATS tanpa memperhatikan data geografis, data iklim, kondisi lokal spesifik, permintaan air, deskripsi proyek dan perkiraan jam produksi serta adanya box controller atau pelindung untuk 
controller/inverter. Selain itu, posisi pemasangan panel PV juga perlu memperhatikan keberadaan tanaman dan/atau bangunan di sekitarnya agak cahaya matahari ke panel PV tidak terhalang. Aspek ini merupakan aspek yang cukup penting yang akan menentukan produktifitas dan efisiensi sebuah PATS. Apabila data mengenai kondisi geografis, iklim, kondisi lokal spesifik, permintaan air, deskripsi proyek dan perkiraan jam produksi tidak ada, maka penentuan lokasi instalasi bisa kurang tepat, jumlah dan ukuran modul PV tidak sesuai dengan kebutuhan. Masalah selanjutnya adalah terkait dengan pemilihan pompa yang salah, ketidakseimbangan antara kebutuhan daya pompa dengan output panel PV. Semua permasalahan ini akan bermuara pada kegagalan sistem dan kemampuan untuk memompa air tidak sesuai dengan yang diharapakan. Ketidakcocokan antara permintaan air dan pola pasokan energi memiliki pengaruh besar terhadap kelayakan ekonomi PATS (Odeh, Yohanis, \& Norton, 2006).

Berdasarkan aspek produk, generator PV menjadi aspek produk yang paling banyak tidak sesuai dengan standar $71 \%$, meskipun sudah ada 22 SNI tentang PV yang meliputi modul, instalsi, pengujian dan konstruksi (Badan Standardisasi Nasional, 2017). Ketidaksesuaian generator PV, inverter/controller dan pompa dengan suatu standar, menjadikan produk tersebut tidak terjamin kualitas dan kinerjanya yang baik secara langsung maupun tidak langsung berpengaruh terhadap kinerja PATS secara keseluruhan. Kelalaian spesifikasi dan metode teknologi menjadi penyebab kegagalan sistem PATS (Fedrizzi, Ribeiro, \& Zilles, 2009). Hal ini karena keandalan sistem PATS berhubungan erat dengan konfiguarsi sistem yang baik (Bakelli, Arab, \& Azoui, 2011).

\section{KESIMPULAN}

Berdasarkan hasil penelitian, Teknologi PATS sangat cocok dikembangkan di Indonesia, khususnya daerah terpencil di Indonesia, dilihat dari aspek ekonomi, sosial dan lingkungan. Standardisasi bisa menjadi salah satu solusi untuk mengurangi aspek kekurangan dan permasalahan PATS saat ini. Faktor-faktor terkait dengan kemungkinan menurunnya efisiensi dan kegagalan sistem, sudah ada dalam parameter-parameter IEC 62253 : 2011. Hasil penelitian melalui gap analisis antara parameter standar dengan instalasi pemasangan PATS di Indonesia, menunjukkan bahwa 51\% aspek dalam IEC 62253 tidak dipenuhi oleh installer atau pengguna yang memungkinkan menurunnya efisiensi bahkan kegagalan sistem PATS, meskipun sebenarnya semua parameter dalam standar IEC 62253 : 2011 dapat dimungkinkan dipenuhi. Aspek paling besar yang tidak dipenuhi adalah terkait dengan buku pegangan operasi dan pemeliharaan untuk personel dan buku pegangan pemeliharaan yang mencakup operasi dan perbaikan. Hal ini sangat memungkinkan ketidaktahuan operator dalam memasang, mengoperasikan dan memelihara sistem.

\section{UCAPAN TERIMAKASIH}

Ucapan terima kasih kami sampaikan kepada Pusat Penelitian dan Pengembangan Standardisasi - Badan Standardisasi Nasional yang telah membiayai penelitian ini melalui APBN Tahun 2017. Ucapan terima kasih juga kami sampaikan kepada anggota tim peneliti dan pihak-pihak yang mendukung penelitian ini.

\section{DAFTAR PUSTAKA}

Arrohman, R. E., Sihana, \& Setiawan, A. A. (2012). Perancangan Sistem Pengangkatan Air Tenaga Surya di Kecamatan Tepus Kabupaten Gunungkidul. Jurnal Teknofisika, 1(1). Retrieved from https://jurnal.ugm.ac.id/teknofisika/article/v iew/5800/4706

Bachtiar, M. (2006). Prosedur Perancangan Sistem Pembangkit Listrik Tenaga Surya Untuk Perumahan (Solar Home System). Jurnal Smartek, 4(3). Retrieved from http://jurnal.untad.ac.id/jurnal/index.php/S MARTEK/article/view/438/375

Badan Standardisasi Nasional. (2017). Daftar SNI. Jakarta. Retrieved from http://sispk.bsn.go.id/SNI/DaftarList?q=pho tovoltaic

Bakelli, Y., Arab, A. H., \& Azoui, B. (2011). Optimal sizing of photovoltaic pumping system with water tank storage using LPSP concept. Solar Energy, 85(2), 288-294. http://doi.org/https://doi.org/10.1016/j.solen er.2010.11.023

Chandel, S. S., Nagaraju Naik, M., \& Chandel, R. (2015). Review of solar photovoltaic water pumping system technology for irrigation and community drinking water supplies. Renewable and Sustainable Energy Reviews, 49(C), 1084-1099. Retrieved from

https://econpapers.repec.org/RePEc:eee:r ensus:v:49:y:2015:i:c:p:1084-1099

Eker, B. (2005). Solar Powered Water Pumping Systems. Trakia Journal of Sciences, 3(7), 
7-11.

Fedrizzi, M. C., Ribeiro, F. S., \& Zilles, R. (2009). Lessons from field experiences with photovoltaic pumping systems in traditional communities. Energy for Sustainable Development, 13(1), 64-70. http://doi.org/https://doi.org/10.1016/j.esd. 2009.02.002

International Electrotechnical Commission. IEC 62253:2011 Photovoltaic pumping systems - Design qualification and performance measurements (2011). Switzerland. Retrieved from https://webstore.iec.ch/publication/6636

Jamil, M., Anees, A. S., \& Rizwan, M. (2012). SPV based water pumping system for an academic institution. American Journal of Electrical Power and Energy Systems, 1(1), $1-7$.

http://doi.org/10.11648/j.epes.20120101.1 1

Kaldellis, J. K., Meidanis, E., \& Zafirakis, D. (2011). Experimental energy analysis of a stand-alone photovoltaic-based water pumping installation. Applied Energy, $88(12)$, 4556-4562. http://doi.org/https://doi.org/10.1016/j.apen ergy.2011.05.036

Len Industri. (2016). SMART PATAS LEN, Solusi Atasi Kekeringan Lahan. Bandung. Retrieved from http://www.len.co.id/smartpatas-len-solusi-atasi-kekeringan-lahan/

Meah, K., Fletcher, S., \& Ula, S. (2008). Solar photovoltaic water pumping for remote locations. Renewable and Sustainable Energy Reviews, 12(2), 472-487. http://doi.org/https://doi.org/10.1016/j.rser. 2006.10.008

Muchsam, Y., Falahah, F., \& Saputro, G. I. (2011). Penerapan Gap Analysis Pada Pengembangan Sistem Pendukung Keputusan Penilaian Kinerja Karyawan (Studi Kasus PT.XYZ). Seminar Nasional Aplikasi Teknologi Informasi (SNATI). Retrieved from http://journal.uii.ac.id/Snati/article/view/217 9

Odeh, I., Yohanis, Y. G., \& Norton, B. (2006). Influence of pumping head, insolation and $\mathrm{PV}$ array size on $\mathrm{PV}$ water pumping system performance. Solar Energy, 80(1), 51-64. http://doi.org/https://doi.org/10.1016/j.solen er.2005.07.009
Pande, P. C., Singh, A. K., Ansari, S., Vyas, S. K., \& Dave, B. K. (2003). Design development and testing of a solar PV pump based drip system for orchards. Renewable Energy, 28(3), 385-396. http://doi.org/https://doi.org/10.1016/S0960 -1481(02)00037-X

Pranoto, S. (2011). Perancangan Inverter Jenis Push-Pull dan On/Off Battery Charger Regulator (BCR) Pada Aplikasi Fotovoltaik Sebagai Sumber Energi Untuk Pompa Air atau Penerangan. Universitas Diponegoro. Retrieved from http://eprints.undip.ac.id/25594/

Rachmi, A., Susanto, T. D., \& Herdiyanti, A. (2014). embuatan Standard Operating Procedure (SOP) Service Desk Berdasarkan Kerangka Kerja Itil V3 dengan Menggunakan Metode Analisis Gap Layanan (Studi Kasus: PT. XYZ , Tangerang). Jurnal Teknik Pomits, 3(2). http://doi.org/10.12962/j23373539.v3i2.81 16

Rahardjo, P. N. (2008). Masalah Pemenuhan Kebutuhan Air Bersih Tiga Desa di Kabupaten Ende. Jurnal Air Indonesia, 4(1), 22-27. Retrieved from http://ejurnal.bppt.go.id/ejurnal2011/index. php/JAl/article/view/267

Rezae, A., \& Gholamian, S. A. (2013). Technical and Financial Analysis of Photovoltaic Water Pumping System for GORGAN, IRAN. International Journal on Cybernetics \& Informatics ( IJCI), 2(2). http://doi.org/10.5121/ijci.2013.2203

Santoso, S., \& Tjiptono. (2001). Riset Pemasaran Konsep dan Aplikasi dengan SPSS. Jakarta: Elex Media Komputindo.

Saputra, F. (2015). Kinerja Pompa Air DC Berdasarkan Intensitas Tenaga Surya. Universitas Muhammadiyah Surakarta. Retrieved from http://eprints.ums.ac.id/36159/27/2. NASKAH PUBLIKASI.pdf

Setiawan, C., Abdillah, N., \& Ismail, Y. (2014). Evaluasi Sistem Pengangkatan Air Tenaga Surya di Gua Plawan, Gunung Kidul, DI Yogyakarta. Prosiding Forum Tahunan Pengembangan IImu Pengetahuan, Teknologi Dan Inovasi Nasional Ke IV, 4. 